\title{
Usulan Perancangan Sistem Informasi Penjualan, Pengendalian Barang, dan Penyimpanan Data pada Toko XYZ (Studi Kasus di Toko XYZ, Lahat, Sumatera Selatan)
}

\author{
Bertha Brigitta $^{1 *}$, Melina Hermawan ${ }^{2}$ \\ ${ }^{1,2}$ Program Studi Teknik Industri, Universitas Kristen Maranatha, Bandung, Indonesia \\ ("brigittabertha2@gmail.com)
}

\begin{abstract}
Abstrak - Toko XYZ merupakan toko grosir/eceran yang berada di Kota Lahat, Sumatera Selatan yang saat ini sedang mengalami penurunan omzet sebesar $27 \%$ dari tahun 2018 hingga saat ini. Penurunan tersebut dikarenakan adanya konsumen yang tidak berbelanja lagi pada Toko XYZ dengan keluhan proses penjualan yang lama dan kesalahan pemberian harga/jumlah/jenis barang. Selain itu pemilik juga mengalami kesulitan dalam mengkontrol barang yang ada di gudang sehingga terjadinya pemesanan barang yang berulang dan barang yang tidak terjual, pemilik juga merasa kesulitan dalam melakukan penagihan hutang karena penyimpanan data yang masih kurang rapi. Masalah-masalah yang ada dalam penelitian ini akan diselesaikan dengan usulan prosedur baru pada Toko XYZ dan penggunaan sistem informasi yang terintegrasi untuk prosedur penjualan, pembelian, data stock gudang, dan penyimpanan nota hutang yang berbentuk rancangan User Interface. Sistem Informasi ini juga akan didukung dengan perbaikan tata letak gudang dengan menggunakan metode Activity Relationship Diagram (ARD).
\end{abstract}

Kata kunci: perancangan tata letak; prosedur; user interface

\section{PENDAHULUAN}

Toko XYZ adalah Toko Kelontong Grosir Eceran yang terletak di Kota Lahat pada saat ini, toko XYZ diketahui mengalami penurunan omzet yang terjadi pada tahun 2018 hingga saat ini, penurunan omzet yang terjadi sebesar $27 \%$. Diketahui bahwa keluhan yang terjadi pada pelanggan yang tidak memilih untuk melakukan transaksi di toko XYZ seperti kesalahan harga barang/jumlah barang/jenis barang, lamanya waktu menunggu, dan pembayaran yang mengharuskan datang ke toko ini masih terjadi pada pelanggan yang saat ini masih melakukan transaksi pembelian pada toko XYZ, hal ini memungkinkan untuk pemilik kehilangkan konsumen di masa yang akan datang jika keluhan diatas tidak di perbaiki.

Selain keluhan diatas terdapat keluhan lain yang didapatkan dari hasil wawancara pemilik dan observasi langsung yang mempengaruhi turunnya omzet, yaitu barang digudang yang sulit dikontrol sehingga menyebabkan kekurangan barang pada saat penjualan, pemesanan yang berulang, dan terkadang juga menyebabkan terjadinya kehilangan barang yang dialami oleh pemilik. Selain itu juga pemilik usaha saat ini masih melakukan pencatatan secara manual dengan mengandalkan nota, namun nota tersebut terkadang hilang sehingga pemilik mengalami kesulitan seperti tidak bisa mengontrol hutang konsumen yang tertera menggunakan nota tersebut, hal ini tentunya sering membuat pemilik kesulitan ketika harus hutang yang masih tersisa.

Identifikasi Masalah:

1. Prosedur penjualan barang, pemesanan barang, penerimaan barang yang belum baik.

2. Prosedur stock opname yang belum jelas

3. Belum adanya penyimpanan data hutang yang baik

4. Penempatan barang yang kurang rapi

Agar penelitian lebih terarah maka digunakan batasan masalah sebagai berikut, penelitian yang dilakukan akan memberikan usulan berupa rancangan user interface dan database, tidak ada penambahan ataupun pengurangan pekerja selama penelitian, dan tidak membahas masalah kepuasan pelanggan. Tujuan dari penelitian ini yaitu membuat rancangan setiap prosedur yang nantinya akan digunakan pada toko XYZ, membuat user interface yang akan digunakan pada toko XYZ, dan memperbaiki penempatan barang yang ada di Gudang. 


\section{STUDI LITERATUR}

\section{A. Konsep Dasar Sistem Informasi}

Sistem dapat dengan mudah didefinisikan sebagai kelompok elemen yang terhubung atau berinteraksi untuk membentuk satu unit. Konsep umum sistem adalah sekelompok komponen yang saling berhubungan yang telah berkolaborasi untuk mencapai tujuan bersama dengan menerima input dan menghasilkan output produksi dalam proses transformasi regular (Indrajani, 2015)

Sistem Informasi Manajemen (SIM) adalah sistem informasi yang sudah terkomputerisasi yang bekerja karena adanya interaksi antara manusia dan komputer . Dengan bantuan manusia, perangkat lunak (program komputer), dan perangkat keras (komputer, printer, dan lain lain) agar berfungsi dengan baik (Kenneth \& Kendall, 2003). Informasi yang diberikan SIM menjelaskan perusahaan atau salah satu sistem utamanya dilihat dari apa yang telah terjadi di masa lalu, apa yang terjadi dan apa yang kemungkinan terjadi di masa depan. (McLeod Jr \& Schell, 2008).

\section{B. Matriks CRUD}

Matriks CRUD adalah suatu perangkat untuk menampilkan dimana setiap proses-proses ini muncul dalam suatu sistem, tabel yang dimana rows menunjukan entitas (dan kemungkinan atribut), kolom menunjukan lokasi dan cell (perpotongan baris dan kolom) menunjukan tingkat akses dimana $C=$ Create, $R=$ Read, $U=$ Update, $D=$ Delete (Jeffrey \& Bentley, 2004).

\section{Activity Relationship Diagram}

Activity relationship (keterhubungan antar aktivitas) menyediakan dasar bagi pengambilan keputusan dalam proses perencanaan fasilitas (Tompkins dkk, 2003) Hubungan-hubungan tersebut meliputi (Tompkins dkk, 2003):

1. Organizational relationship, dipengaruhi oleh struktur hubungan pengendalian dan pelaporan dalam organisasi.

2. Flow relationship, termasuk aliran material, orang, peralatan, informasi, dan uang.

3. Control relationship, termasuk sentralisasi atau desentralisasi kontrol material, real time atau batch inventory control, shop floor control, dan level of automation and integration.

4. Environmental relationship, termasuk pertimbangan keselamatan dan temperatur, kebisingan, asap, kelembaban, dan debu.

5. Process relationship, seperti floor loadings, kebutuhan untuk water treatment, proses kimia, dan pelayanan khusus yang lain

Selain tinjauan pustaka di atas, terdapat juga beberapa tinjuauan pustaka yang didapatkan dari jurnal-jurnal penelitian yang membahas pengembangan sistem informasi pada suatu tempat. Ringkasan mengenai jurnaljurnal tersebut akan dibahas dalam penjelasan berikut ini.

Despita (2017). Jurnal membahas tentang Analisis dan Perancangan Sistem Informasi Persediaan Barang Menggunakan Metode First In First Out (FIFO) Pada PT. Shukaku Jambi, jurnal ini membahas tentang pengembangan sistem informasi dengan metode prototype yang memiliki tujuan untuk membenahi sistem persediaan dengan tujuan meningkatkan laba perusahaan.

Helpi (2018). Jurnal membahas tentang Perancangan Sistem Informasi Registrasi Mahasiswa pada Universitas Islam Kuantan Singingi, Teluk Kuantan, jurnal ini membahas tentang pengembangan sistem informasi pada layanan administrasi akademik, untuk membantu mahasiswa dan dosen dalam melakukan registrasi.

Deni \& Yuda (2019). Jurnal membahas tentang Perancangan Sistem Informasi Penjualan Di Toko Tanaka Optikal Bandung, jurnal ini membahas pengembangan sistem informasi yang dilakukan dengan tujuan untuk mempermudah pemilik dalam melakukan transaksi dan perekapan data transaksi.

Fatchan \& Dilla (2020). Jurnal membahas tentang Sistem Informasi Penjualan Sembako Pada Toko Srimukti Pasar Serang Kecamatan Serang Baru Berbasis Android, jurnal ini membahas tentang bagaimana mengimplementasikan penjualan sembako berbasis android dengan tujuan agar transaksi penjualan pada Toko Srimukti menjadi lebih aman dan akurat. 


\section{METODOLOGI}

\section{A. Identifikasi Masalah}

Melakukan identifikasi masalah untuk mencari tahu serta menganalisa permasalahan yang terdapat pada Toko XYZ, Lahat, Sumatra Selatan.

\section{B. Pengumpulan Data dan Observasi}

Pengumpulan data dapat dilakukan dalam berbagai cara, setting, dan sumber. Bila dilihat dari segi cara atau teknik pengumpulan data, teknik pengumpulan data dapat dilakukan dengan menggunakan interview (wawancara), observasi (pengamatan), dan gabungan dari keduanya (Sugiyono, 2004). Pada penelitian ini, digunakan 2 teknik pengumpulan data yaitu observasi dan wawancara. yang dilakukan langsung pada Toko XYZ, dalam tahapan ini peneliti juga mencari kekurangan-kekurangan yang ada pada sistem dengan menggunakan metode PIECES (Performance, Information, Economic, Control, Efficiency, Service) untuk nantinya bisa menjadi patokan dalam perbaikan yang akan dilakukan pada penelitian.

\section{Analisis PIECES dan Kebutuhan Sistem}

Pada tahapan ini dilakukan analisis dari hasil wawancara PIECES untuk mengetahui kekurangan dari sistem. Ketika hasil telah dianalisis maka kekurangan dari sistem yang ada pada saat ini dirangkum menjadi kebutuhan sistem. Berikut merupakan kebutuhan perbaikan Sistem Informasi pada Toko XYZ:

1. Sistem penjualan yang bisa memberikan harga barang dan perhitungan total yang akurat.

2. Sistem yang menyediakan informasi terupdate untuk stok barang yang terintegrasi dengan sistem penjualan.

3. Sistem notifikasi yang bisa memberikan info hutang jatuh tempo, barang hampir habis, dan barang expired.

4. Sistem yang memiliki informasi penempatan barang di gudang.

5. Sistem yang bisa menyimpan data hutang, piutang, barang masuk, dan data penjualan.

\section{Perancangan Sistem}

Tahapan ini akan menjelaskan gambaran detail dari sistem yang akan dibangun dengan metode DFD (Data Flow Diagram), Basis Data, ERD (Entity Relationship Diagram) dan CRUD. Berikut penjelasan dari gambaran perancangan sistem:

1. Perancangan DFD untuk setiap prosedur.

Selanjutnya dilakukan perancangan DFD level 0 dan level 1, yang akan menggambarkan bagaimana infromasi berpindah dari satu proses ke proses lainnya. Pada penelitian ini DFD level 0 dan level 1 dibuat untuk prosedur login, penjualan, pemesanan barang, masuk barang, stock opname, penagihan hutang, dan pembukuan. Berikut merupakan gambar DFD level 1 untuk salah satu prosedur, yaitu prosedur penjualan. 


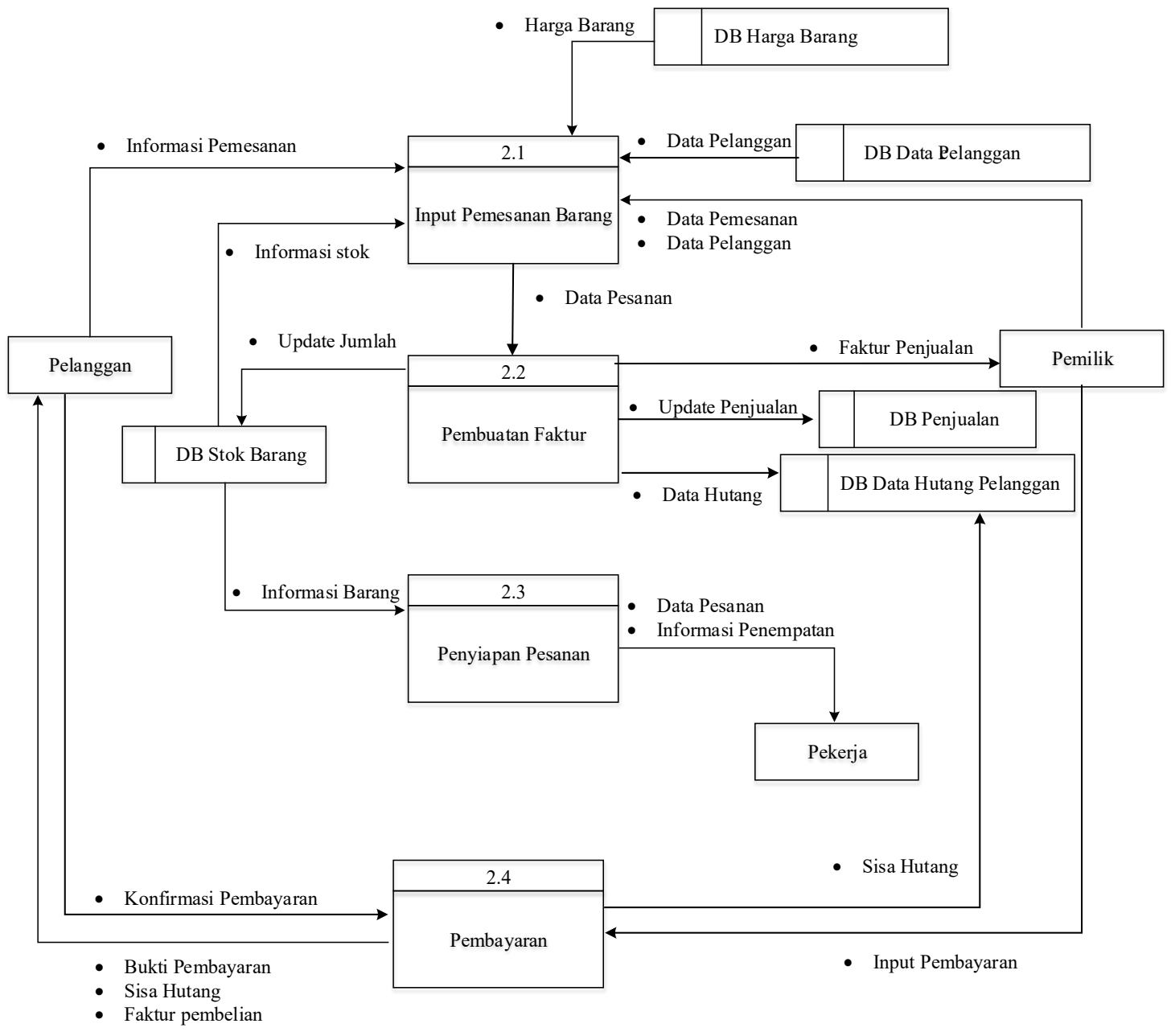

Gambar 1. Data Flow Diagram Level 1 Prosedur Penjualan

2. Perancangan Basis Data yang digunakan

Dalam mendukung jalannya Sistem Informasi yang dirancang, maka diperlukan adanya perencanaan basis data, berikut merupakan salah satu rancangan basis data yang digunakan:

Tabel 1

Database Stok Barang

\begin{tabular}{|l|l|l|l|l|l|}
\hline \multicolumn{7}{|c|}{ Stok Barang } \\
\hline Kode Barang & Nama Barang & Jumlah Stok & Penempatan & Minimum Stok & Expired \\
\hline & & & & & \\
\hline \\
\hline
\end{tabular}

3. Perancangan ERD (Entity Relationship Diagram)

Perancangan ERD dilakukan dengan tujuan untuk bisa menggambarkan hubungan setiap database dengan lebih jelas pada setiap prosedurnya, berikut merupakan salah satu ERD yaitu ERD penjualan: 


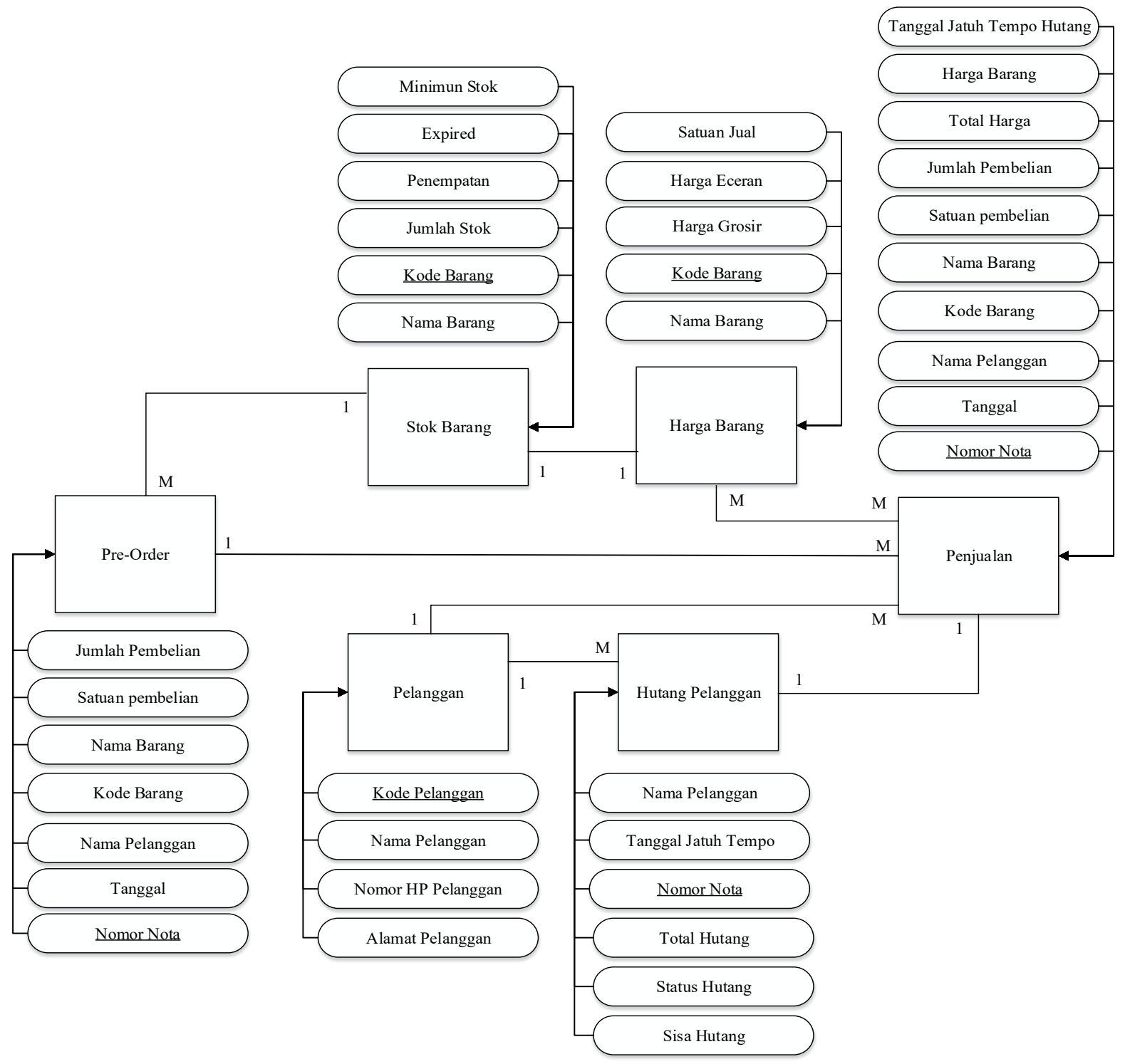

Gambar 2. Entity Relationship Diagram Penjualan

4. Perancangan Matriks CRUD (Create, Read, Update, Delete)

Matriks CRUD digunakan untuk menentukan hak akses dari setiap entitas yang ada pada Sistem Informasi yang ada pada Toko XYZ, dalam penelitian ini terdapat 3 entitas yang akan terlibat dalam sistem yaitu pemilik, pelanggan, dan pekerja. Berikut menurpakan salah satu matriks CRUD:

Tabel 2

Matriks CRUD

\begin{tabular}{|l|c|c|}
\hline \multicolumn{1}{|r|}{ Entitas } & Pemilik & Pekerja \\
\hline \multicolumn{2}{|c|}{ Stok Barang } \\
\hline Kode Barang & CRD & $\mathrm{R}$ \\
\hline Nama Barang & CRUD & $\mathrm{R}$ \\
\hline Jumlah Stok & CRUD & $\mathrm{R}$ \\
\hline Penempatan & CRUD & $\mathrm{R}$ \\
\hline Minimum Stok & CRUD & $\mathrm{R}$ \\
\hline Expired & CRUD & $\mathrm{R}$ \\
\hline
\end{tabular}




\section{E. Perancangan Activity Relationship Diagram Untuk Tata Letak Toko dan Gudang.}

Untuk mendukung berjalannya Sistem Informasi yang telah dirancang, maka dilakukan perbaikan Tata Letak Gudang dan Toko pada Toko XYZ, perbaikan ini menggunakan metode ARD yang didukung dengan pelabelan setiap jenis barang.

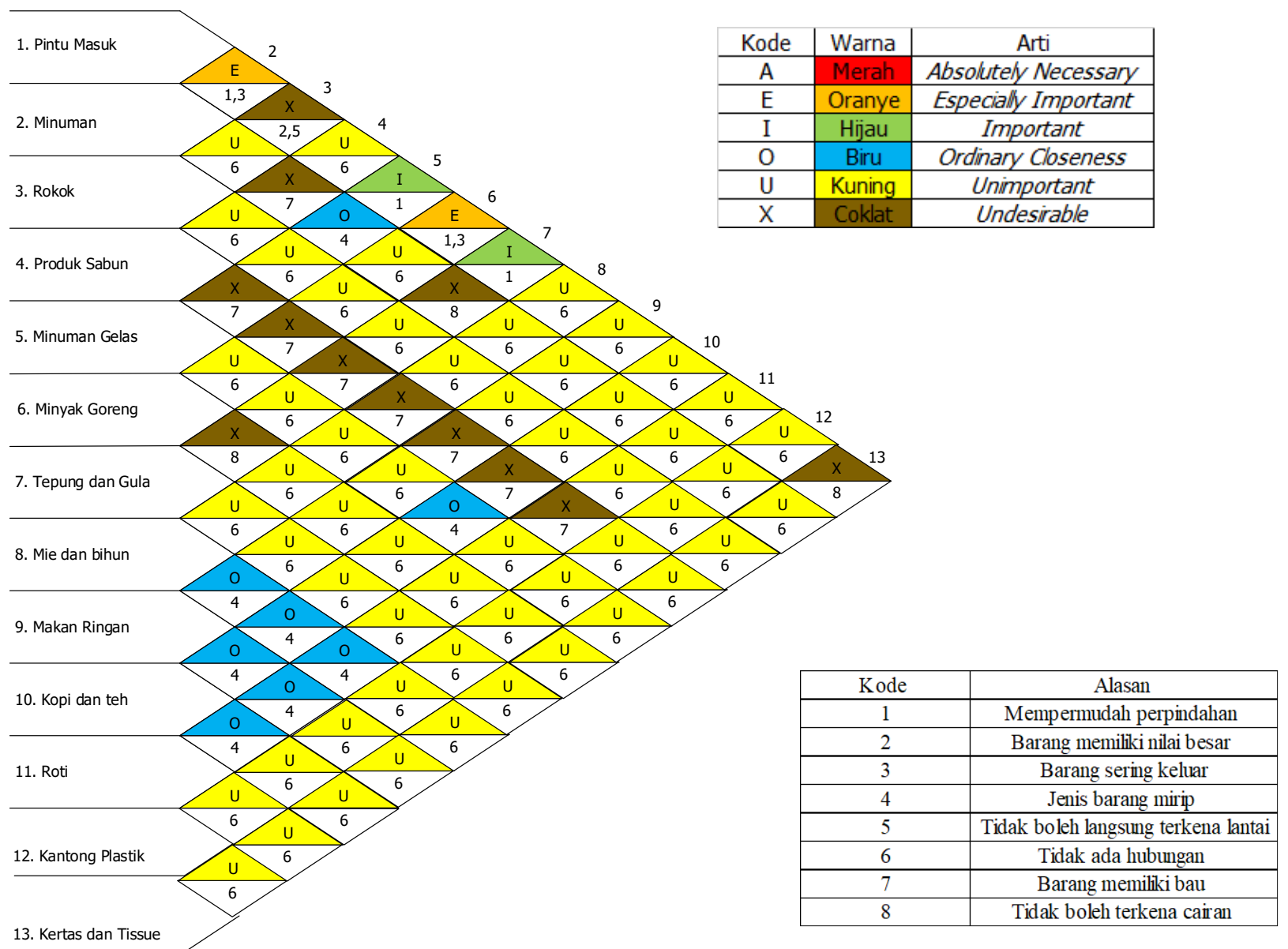

Gambar 3. ARD Gudang

\section{HASIL DAN DISKUSI}

Dari pengolahan data yang telah dilakukan, penelitian ini menghasilkan 2 perbaikan utama, yaitu perbaikan dengan menerapkan Sistem Informasi yang terintergrasi dan perbaikan tata letak untuk mendukung jalannya Sistem Informasi.

\section{A. Perancangan User Interface}

Hasil akhir dari perancangan sistem adalah user interface yang nantinya akan digunakan oleh entitas yang bersangkutan, dengan tujuan penyelesaian masalah, Berikut rancangan user interface yang digunakan pada toko XYZ: 


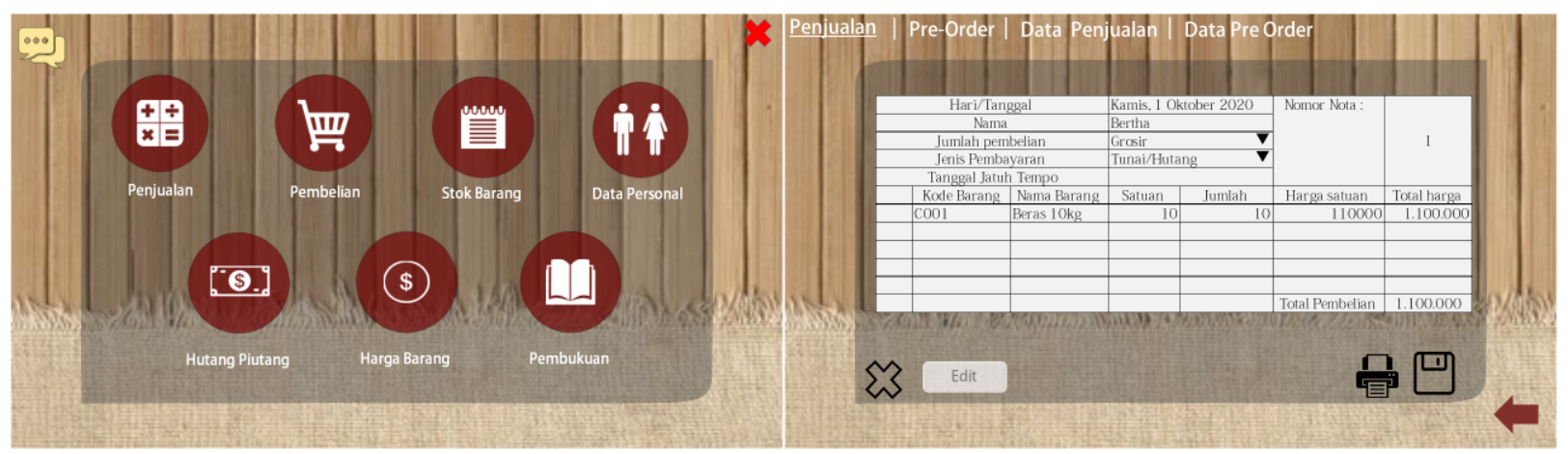

Gambar 4. User Interface Halaman Awal dan Halaman Penjualan

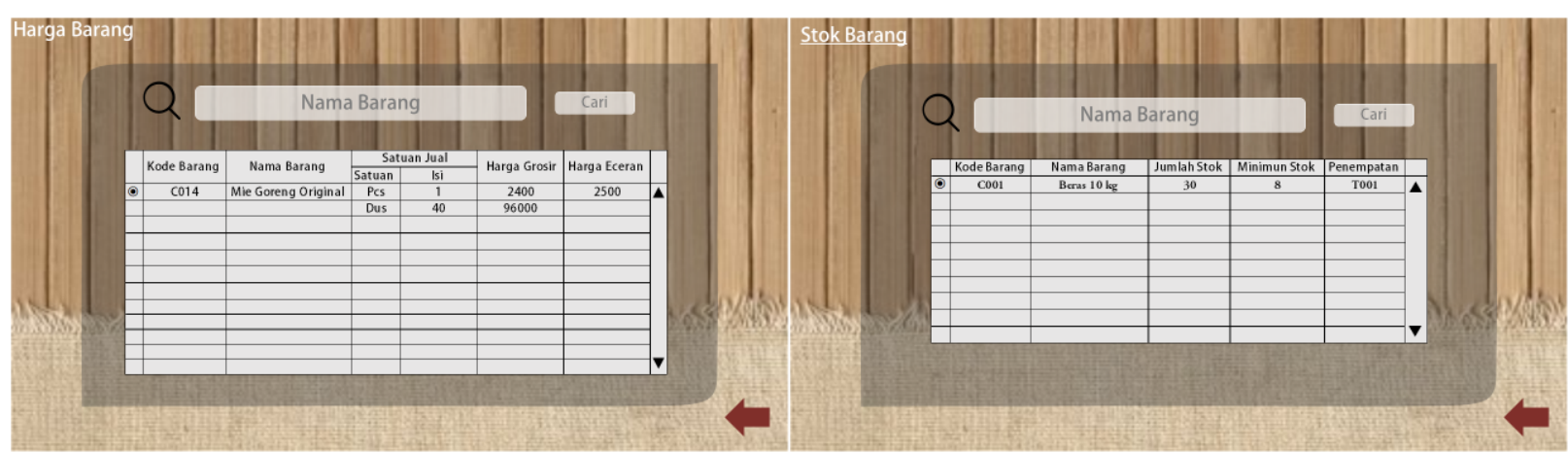

Gambar 5. User Interface Halaman Harga Barang dan Halaman Stok Barang

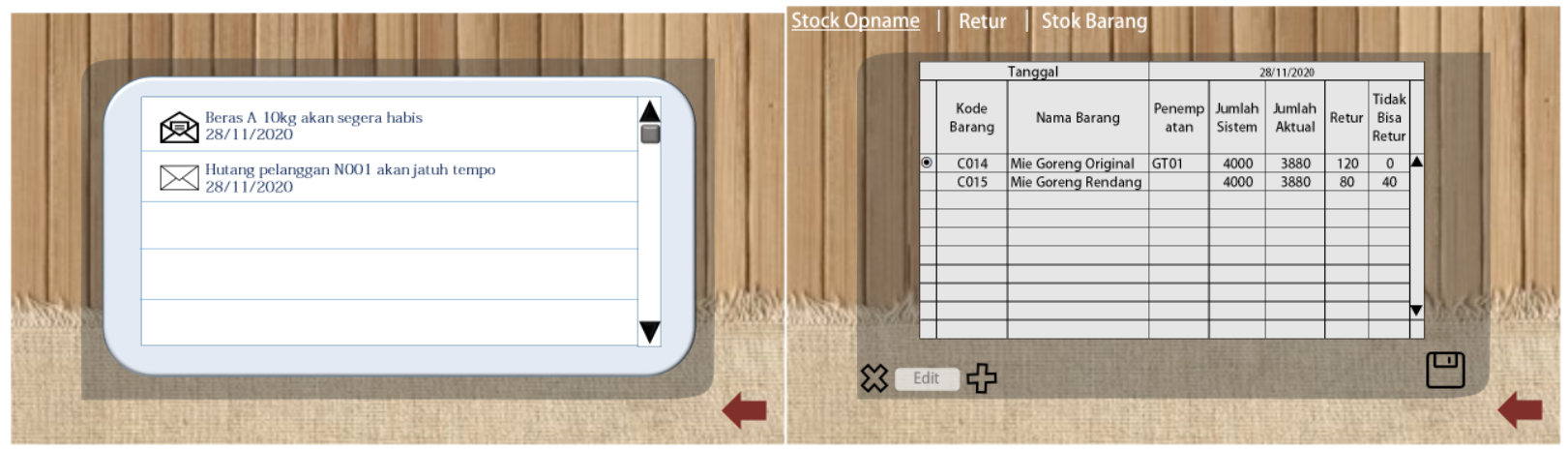

Gambar 6. User Interface Halaman Notifikasi dan Halaman Stock Opname

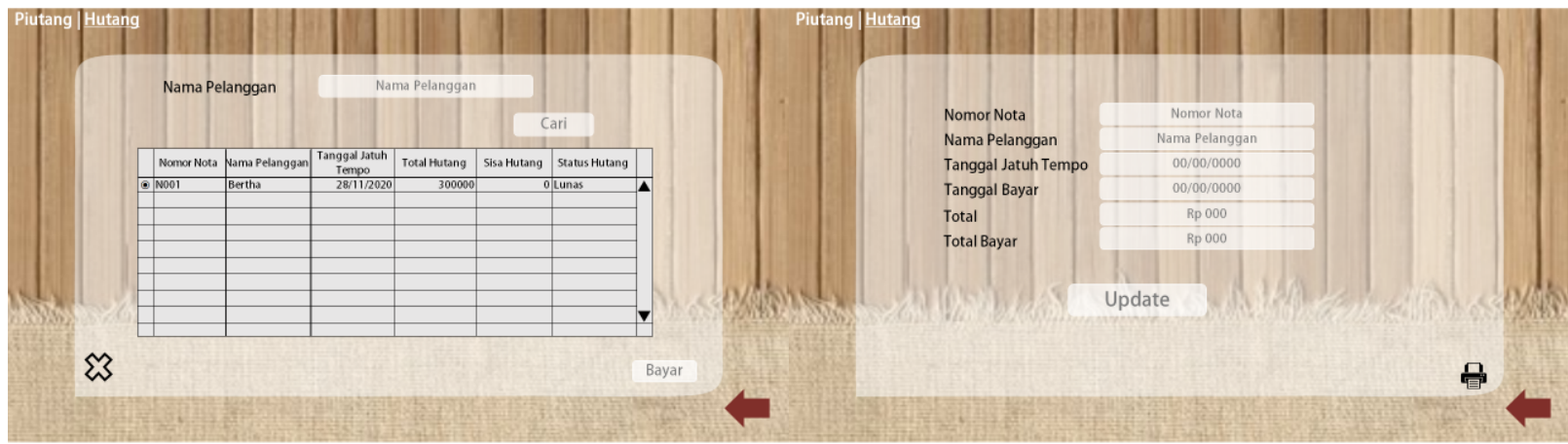

Gambar 7. User Interface Halaman Hutang dan Halaman Pembayaran Hutang. 


\section{B. Usulan Tata Letak Gudang dan Toko}

Usulan tata letak untuk Gudang dan Toko dengan menggunakan metode ARD (Activity Relationship Diagram). Usulan ini bertujuan untuk membenahi layout bagian Gudang dan Toko sesuai dengan tingkat kepentingannya. Usulan ini juga menggunakan metode First In First Out yang diterapkan untuk penyimpanan barang.

\section{Gudang 1}

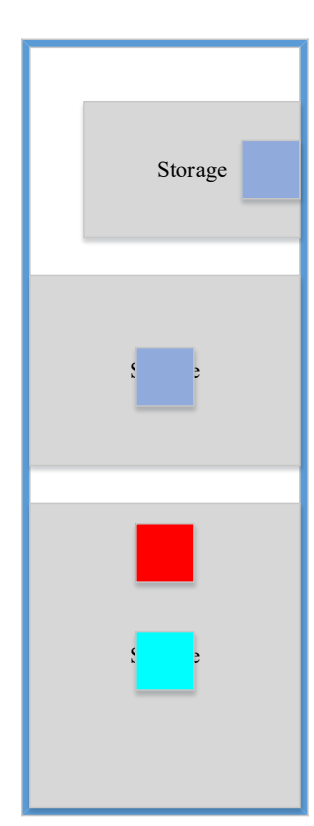

Lantai 1,5 : Gudang

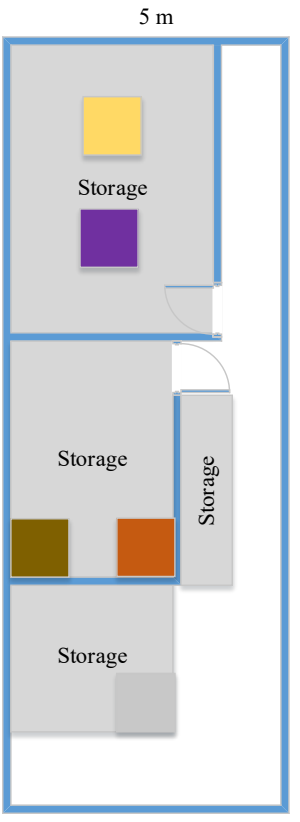

Lantai 2 : Gudang

\section{Keterangan}

1. Pintu Masuk

2. Minuman

3. Rokok

4. Produk Sabun

5. Minuman Gelas

6. Minyak Goreng

7. Tepung dan Gula

8. Mie dan bihun

9. Makan Ringan

10. Kopi dan teh

11. Roti

12. Kantong Plastik

13. Kertas dan Tissue

\section{Gudang 2}

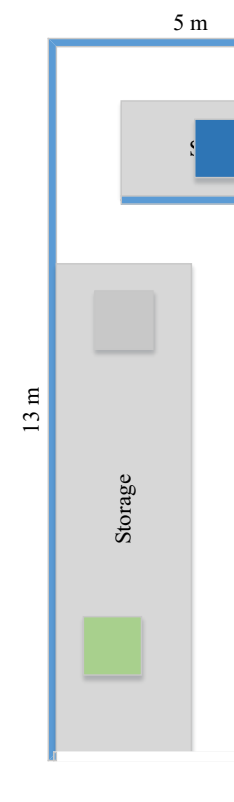

Lantai 1

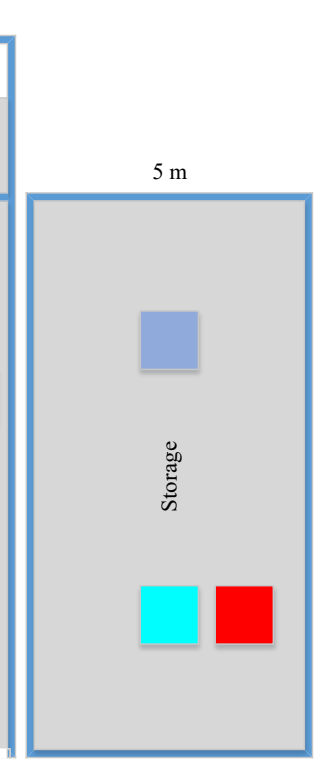

Lantai 1,5

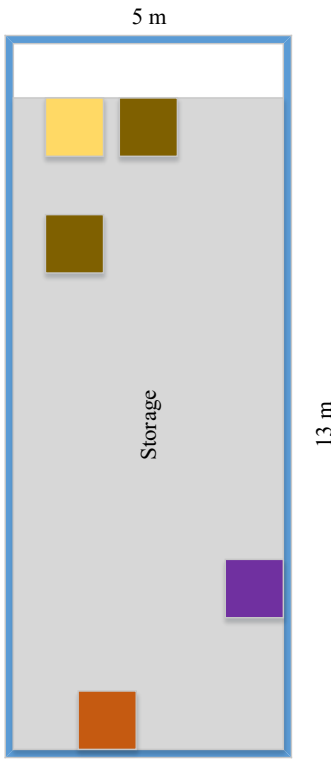

Lantai 2

Gambar 8. Tata Letak Gudang 


\section{KESIMPULAN}

Kesimpulan yang dapat diambil dalam Sistem Informasi pada Toko XYZ ini adalah sebagai berikut:

1. Masalah waktu penjualan yang lama, telah terselesaikan dengan adanya sistem informasi untuk melakukan pengecekan stok barang yang dapat dilihat pada gambar 3 .

2. Masalah kesalahan pemberian harga/jenis/jumlah barang telah terselesaikan dengan adanya sistem informasi yang memiliki informasi tentang harga dan jenis barang, serta sistem informasi yang bisa melakukan pencatatan pembelian barang, halaman user interface dapat dilihat pada gambar 3 dan gambar 4.

3. Kesulitan melakukan kontrol barang di gudang telah diselesaikan dengan cara perbaikan tata letak gudang dengan menggunakan metode ARD, penyusunan barang, serta sistem informasi yang memiliki kemampuan untuk menyimpan dan mengupdate jumlah barang dalam gudang yang dapat dilihat pada gambar 4.

4. Kesulitan dalam melakukan penagihan hutang akibat penyimpanan nota yang kurang tertata telah diselesaikan dengan adanya sistem informasi yang bisa menyimpan data hutang dan pengingat jatuh tempo, dapat dilihat pada gambar 5 dan 6.

5. Masalah pemesanan berulang yang dialami pemilik telah diselesaikan dengan menggunakan data persediaan dan pengingat persediaan ketika mendekati batas safety stock, dapat dilihat pada gambar 4 dan 5.

\section{DAFTAR PUSTAKA}

Fatchan, Muhammad \& Dilla Eki, S.W. (2020). Perancangan Sistem Informasi Penjualan Sembako Pada Toko Srimukti Pasar Serang Kecamatan Serang Baru Berbasis Android. (Vol 10 No 4 Juni 2020 ISSN: 24073903) [Universitas Pelita Harapan]

Indrajani, S. K. M. M. (2015). Database Design. Elex Media Komputindo.

Kendall, Kenneth E. Dan Kendall, Julie E., 2003, Analisis dan Perancanga Sistem Edisi Kelima Jilid 1 dan Jilid 2, Jakarta: Prenhallindo.

L. Whitten, Jeffrey, \& D. Bentley,Lonnie .(2004). Metode Desain dan Analisis Sistem Edisi 6, penerbit andi, Yogyakarta

McLeod Jr, R., \& Schell, G. P. (2008). Sistem Informasi Manajemen Edisi 10. Jakarta: Salemba Empat.

Meisak, Despita (2017). Analisis Dan Perancangan Sistem Informasi Persediaan Barang Menggunakan Metode FIFO Pada PT.Shukaku Jambi (Mediasisfo Vol.11, No.2) [STIKOM Dinamika Bangsa]

Nopriandi, Helpi (2018). Perancangan Sistem Informasi Registrasi Mahasiswa. (Jurnal Teknologi Dan Open Source vol 1 no 1) [Universitas Islam Kuantan Singingi]

Rusdianto, Denny \& Yuda Satia (2019). Perancangan Sistem Informasi Penjualan Di Toko Tanaka Optikal Bandung. (J-Sika vol 01. No 01) [Universitas Bale Bandung]

Sugiyono. (2004). Metode Penelitian Bisnis. Bandung: Alfabeta.

Tompkins J.A., White J.A., Bozer, Tanchoco J.M.A. (2003). Facilities Planning, Third Edition, John Willey \& Sons, Inc, California. 